\title{
Classroom teachers' online teaching experiences during the COVID-19 pandemic: The perspective of technological pedagogical content knowledge
}

\author{
Mehmet Hayri Sarı ${ }^{1}$ and Hilal Keser ${ }^{2}$ \\ ${ }^{1}$ Nevsehir Haci Bektas Veli University, Nevsehir, Turkey (ORCID: 0000-0002-7159-2635) \\ ${ }^{2}$ Ministry of National Education, Nevsehir, Turkey (ORCID: 0000-0002-7458-2096)
}

\begin{abstract}
This qualitative study aims at evaluating the online teaching experiences of classroom teachers during the New Coronavirus Disease (COVID-19) period in terms of the Technological Pedagogical Content Knowledge (TPACK). The interviews were conducted with 17 classroom teachers within the scope of the current research. The data were collected via open-ended semi-structured interview questions. As a result of the analysis of the data, the classroom teachers considered themselves competent in the components of Technological Knowledge (TK), Content Knowledge (CK), Pedagogical Knowledge (PK) and Pedagogical Content Knowledge (PCK), they did not consider themselves competent in the Technological Content Knowledge (TCK) and Technological Pedagogical Knowledge (TPK) components, which were the result of the integration of these components with technology. When the participants were addressed in terms of the online teaching experiences, technology uses, competencies and professional training needs as a whole during the COVID-19 period, it was found that they did not use digital tools primarily for pedagogical purposes. Therefore, the teachers needed extensive pedagogical support when designing digital teaching. All of these results suggest that 21st century teachers need to develop their knowledge and skills in terms of CK, PK, TCK, and TPK that emerge with the transfer of such knowledge to technological processes and TPACK that forms the intersection of all information.
\end{abstract}

Keywords: Technological pedagogical content knowledge; COVID-19; Distance education; Epidemic; Online education; Technology

Article History: Submitted 30 June 2021; Revised 17 November 2021; Published online 31 December 2021

\section{Introduction}

The new Coronavirus Disease (COVID-19) first appeared on December 1, 2019 in Wuhan, China, and later on it has shown its effects in many countries of Europe, America and Asia continents (World Health Organization [WHO], 2020a). COVID-19, which was declared as a global pandemic by the World Health Organization (WHO, 2020b) on March 11, 2020, had negative effects in many areas of human life such as health, economy and education.

Countries, within their own contexts, took a series of decisions in order to minimize the impact of the global pandemic on social life and to prevent further spread of the pandemic. Among these

\footnotetext{
Address of Corresponding Author

Mehmet Hayri Sarı, PhD, Nevsehir Haci Bektas Veli University, Faculty of Education, 50300, Nevşehir, Turkey.

$\triangle$ mhsari@nevsehir.edu.tr
}

How to cite: Sarı, M. H. \& Keser, H. (2021). Classroom teachers' online teaching experiences during the COVID-19 pandemic: The perspective of technological pedagogical content knowledge. Journal of Pedagogical Research, 5(4), $251-269$. https://doi.org/10.33902/JPR.2021474706 
decisions, there was also the determination to transform education-training processes from face-toface education to distance education. The decision for distance education, which was firstly taken in China on February 16, 2020, spread to 45 countries on March 13, and 166 countries decided to shift from face-to-face education to distance education and closed schools at all education levels on March 26. Finally, this number reached the peak after a total of 172 countries having taken the decision for distance education on April 1, 2020 (United Nations Educational, Scientific and Cultural Organization [UNESCO], 2020).

The transition to asynchronous learning environments was initiated through broadcastings of local Education Information Network (EBA) within the Ministry of National Education (MoNE) on the Turkish Radio and Television (TRT) on March 23 in Turkey at all levels of education (Ministry of National Education [MoNE], 2020a). Within the scope of the decisions taken after the recommendations by the Scientific Committee of the Ministry of Health, it was decided that the education would be conducted in an asynchronous way firstly until April 30 (MoNE, 2020b), and later on until May 31 (MoNE, 2020c). Then, the students went on summer vacation.

MoNE conducted betterment works in terms of the Internet infrastructure, software and hardware during the summer vacation. After these works, the make-up program regarding the remaining subjects and objectives of the 2019-2020 academic year through distance education was initiated on August 31, 2020. There was a transition to online education process at all educational levels except universities (MoNE, 2020d). With this process, all teachers started providing their students with a synchronized learning-teaching environment with live lessons.

The teachers and students in Turkey, as in many other countries, were forced to an emergent transition from traditional classes to online classes without an adequate time for preparation. COVID-19 transformed homes around the world into classrooms in weeks, even if it was not in days (Bayrakdar \& Guveli, 2020). However, many teachers had little or no experience of teaching from home. Even for those teachers who taught online before, shifting to a fully online teaching has become a challenge (Sykes, 2020). Therefore, the transition from face-to-face education to distance education brought about the change of some roles in the learning-teaching process. Teachers constitute, undoubtedly, the biggest part of the change in these roles (Ely, 1992; Tezci \& Perkmen, 2013). The role of the teacher changed from the traditional "blackboard-speakingtextbook" based teaching approach to directing learning and helping students achieves their own goals due to the use of technology at the highest level (Saban, 2007). The COVID-19 period left teachers to face the situation of need to use technology appropriately and effectively. The teachers have to know what kinds of materials are available, how to use them, why they should be used, when they should be used, and how to integrate them into the learning-teaching process in online education.

Numerous models were developed to assist teachers in their proficiency of how to integrate technologies into the learning-teaching process, to know how to use them, and to design learning opportunities efficiently and effectively with their skills (Brower \& Vlachopoulos, 2018) such as TPACK (Mishra \& Koehler, 2006), technology integration planning (Roblyer, 2006), information and communication technology integration (Wang \& Woo, 2007). In this study, online teaching experiences of classroom teachers during the COVID-19 period were examined within the framework of the TPACK model. The TPACK model was used in this study as it is a frequently used as a model in planning and / or analyzing the process of integrating technology into the learning environment (Chai et al., 2013; Koehler et al., 2012; Voogt et al., 2012).

\subsection{Theoretical Framework}

\subsubsection{Technological pedagogical content knowledge}

TPACK framework refers to the knowledge that teachers need in order to integrate technology into the teaching process successfully (Mishra \& Koehler, 2006; Mishra, 2019). Mishra and Koehler presented the TPACK model that they developed by adding TK to Shulman's (1987) PCK theory, which consists of PK and CK (See Figure 1; Mishra \& Koehler, 2006). When each of these 
knowledge areas (TK, PK, and CK) is considered as a circle, the point where these circles intersect with each other is named TPACK (Mishra \& Koehler, 2006).

Figure 1

TPACK Framework (source: http://tpack.org/). Reproduced by permission of the publisher, (C) 2012 by tpack.org.

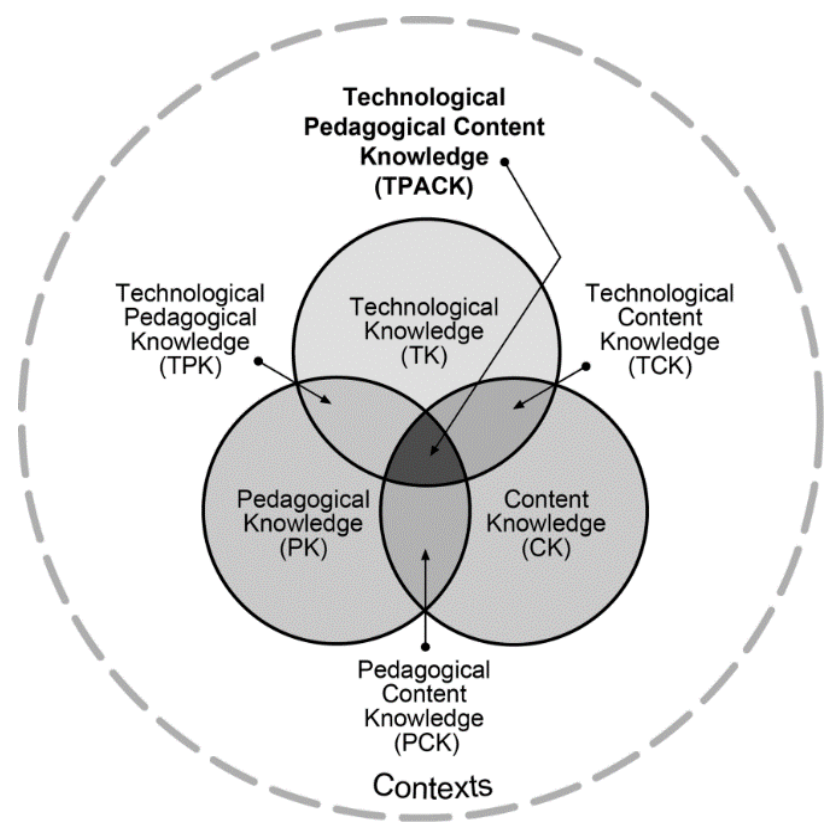

TPACK framework highlights an interaction among technology, pedagogy and CK specific to learning environment (Goradia, 2018). TPACK is a framework which defines the knowledge that teachers need to use ICT effectively during the process of teaching students with different interests and abilities (Heitink et al., 2017). For this reason, TPACK is a model developed to see teachers' ability to integrate technology into the teaching process. In this model, it is argued that the effectiveness of a teacher depends on Technological Knowledge (TK), PK and CK and the ability to blend these types of knowledge (Mishra \& Koehler, 2006). TK, within the TPACK structure, refers to the extent to which teachers can use different technologies. TK involves the use of both general Information and Communication Technologies (ICT) tools (the Web researches, e-portfolios, etc.) related to the subject area, and ICT tools and software specific to the subject area related to teachers' professional fields (Cox \& Graham, 2009; Mishra \& Koehler, 2006). PK refers to the teachers' level of understanding of the necessary conditions for learning and teaching approaches and methods. PK is concerned with teaching methods and their application to promote student learning. It requires knowledge of classroom management skills, teaching strategies and students' learning processes (Cox \& Graham, 2009; Mishra \& Koehler, 2006). CK refers to the teachers' level of understanding of knowledge about the subject to be taught and the relationship among different knowledge areas within the subject. Briefly, it is connected with the knowledge regarding topic. Overall, it is subject area knowledge, and it involves the type of knowledge on which subjects should be included in a curriculum (Cox \& Graham, 2009; Mishra \& Koehler, 2006).

Four new information fields are formed as a result of the interaction of these basic information (TK, PK, and CK) with each other. These are PCK, TCK, TPK and TPACK (Mishra \& Koehler, 2006). PCK refers to the knowledge and awareness that teachers need in order to transform teaching content into descriptions that make them understandable to students. TCK refers to the knowledge that teachers need in order to transform technology in a way that helps learning course content. TPK refers to the knowledge that teachers need in order to include students into learning process in an active way and to design proper learning conditions that motivate them to learn. TPACK refers to the knowledge that teachers need in order to present course content in a 
pedagogically meaningful way and also to form proper conditions that involve students into learning process (Mishra \& Koehler, 2006).

In conclusion, the seven-structured TPACK framework involves technology tools knowledge (TK), teaching methods knowledge (PK) and CK as three main sources of teacher's technology integration expertise. The other four knowledge types involve Shulman's PCK included in this framework according to teachers' knowledge regarding teaching methods (PCK).

\subsection{Technological Pedagogical Content Knowledge Competencies of Teachers}

Teachers need to realize the potential of digital technology in daily teaching practices and use them successfully (Spiteri \& Chang-Rundgren, 2020). ICT use in classrooms is a common practice for many schools, however, technological tools change greatly over time while teachers' teaching practices generally do not (Browne, 2019). Teachers have a great responsibility for developing and updating their TK and competencies nowadays, because the only way to achieve desired objectives in courses is to integrate technology into classroom effectively in an environment where technology affects education greatly (Acar, 2021; Atakan, 2019).

Considering findings obtained from the studies, it was revealed that teachers and prospective teachers of different branches had low TPACK competences (Amhag et al., 2019; Atakan, 2019; De Freitas \& Spangenberg, 2019; Erdogan \& Mutluoglu, 2016; Fathi \& Yousefifard, 2019; Karadeniz \& Vatanarttiran, 2015; Roussinos \& Jimoyiannis, 2019). The findings obtained through the analysis of use, competence and professional training need reported by teachers in the digitalization of teaching show that they do not use digital tools primarily for pedagogical purposes (Amhag et al., 2019). According to the research findings, it was seen that teachers and prospective teachers had superiority in three components of TPACK, which are TK, PK, and CK. However, it was observed that teachers and prospective teachers had inferiority in the components of TPACK, which are PCK, TCK, TPK in comparison to the other three components of the TPACK (Nazari et al., 2019; Polly \& Orrill, 2016; Riandi et al., 2018; Roussinos \& Jimoyiannis, 2019). The situation is also similar in Turkey (Erdogan \& Mutluoglu, 2016; Karadeniz \& Vatanarttiran, 2015). While teachers and prospective teachers have lower competencies of TK, PK and higher competencies of CK, they are less competent in PCK, TCK, TPK and TPACK in comparison to the other three components (TK, PK, CK) (Erdogan \& Mutluoglu, 2016; Karadeniz \& Vatanarttiran, 2015). All of these findings obtained from the studies show that teachers cannot integrate digital technologies into learningteaching processes effectively due to the gap between information and communication technology skills and knowledge of effective pedagogical approaches (Roussinos \& Jimoyiannis, 2019). Although teachers and teacher candidates are competent in the individual components of TPACK (TK, CK and PK), they are not competent enough in the integration of these components for effective teaching (Mutanga et al., 2018; Roussinos \& Jimoyiannis, 2019). The CK of TPACK skills of 21st century teachers shows that teachers need to improve themselves in terms of pedagogic and technologic aspects (Riandi et al., 2018). The TPACK competencies of teachers have become a topic of inquiry since COVID-19, because how teachers teach during online teaching affects how profoundly students learn after facing the global pandemic according to Burgess and Sievertsen (2020). The evaluation of the experiences of teachers during online teaching in terms of TPACK is important in revealing in which aspects of TPACK they need more training.

In this paper, it was aimed to evaluate classroom teachers' online teaching experiences during COVID-19 in terms of TPACK. The reason why the study was carried out with classroom teachers is that the teachers working at primary schools have to teach subjects of various courses (science, maths, social sciences, life science, Turkish, etc.). This situation requires them to be content knowledgeable profoundly at every subject. For this reason, classroom teachers' being knowledgeable at a wide range of competence areas such as organizing learning, classroom management, subject-specific teaching strategies, using technology in different courses during online teaching is essential for a successful teaching and technology integration. With the current 
study, it was aimed to find out the TPACK competences of classroom teachers in online education during COVID-19. In this regard, this study sought to answer the following research question:

$>$ What kind of experiences did the classroom teachers have during their online teaching process in COVID-19 era in terms of TPACK competencies?

\section{Method}

\subsection{Research Design}

A phenomenological research design as adopted utilized to examine what classroom teachers experienced in online education during the COVID-19 pandemic period. The purpose in a phenomenological design is to explore the experiences of the individuals regarding a phenomenon (Creswell, 2007).

\subsection{Participants}

The classroom teachers who conducted their courses in an online mode after March, 2020 through distance education were the target group of the current study. Therefore, the criterion sampling, one of the purposeful sampling methods, was used for choosing the participants (Creswell, 2012; Yildirim \& Simsek, 2013). The criterion was defined in a way that the classroom teachers' professional seniority ranged 1-10 years, 11-20 years, and 21 years and above. Moreover, the participants were chosen among the teachers serving in a village (V), a town centre (TC), and a province centre (PC) as a secondary criterion of the study. Demographic profiles of the participants were presented in Table 1.

Table 1

Demographic profiles of the participants

\begin{tabular}{llllllllllll}
\hline Coded Names & FT1 & FT2 & MT1 & FT3 & FT4 & MT2 & MT3 & FT5 & FT6 & MT4 & MT5 \\
\hline $\begin{array}{l}\text { Professional Seniority } \\
\text { Year) }\end{array}$ & 7 & 4 & 6 & 2 & 7 & 11 & 6 & 7 & 20 & 17 & 20 \\
\hline Place Served & TC & PC & V & V & V & V & V & TC & PC & PC & PC \\
\hline Grade Taught & 3 & 3 & 3 & 2 & 4 & 4 & 4 & 4 & 3 & 4 & 3 \\
\hline Coded Names & FT7 & FT8 & MT6 & FT9 & FT10 & MT7 & & & & & \\
\hline $\begin{array}{l}\text { Professional Seniority } \\
\text { Year) }\end{array}$ & 19 & 6 & 31 & 13 & 14 & 6 & & & & \\
\hline Place Served & TC & TC & PC & TC & PC & V & & & & \\
\hline Grade Taught & 2 & 2 & 3 & 4 & 3 & 2 & & & & & \\
\hline
\end{tabular}

${ }^{*}$ Note. FT: Female Teacher; MT: Male Teacher

As illustrated in Table 1, the interviews were conducted with 17 classroom teachers within the scope of the current research. There were 7 male teachers and 10 female teachers. When we analyze the professional seniority, it ranged from 2 years (the lowest) to 31 years (the highest). There were 6 teachers serving in a village, 6 teachers serving in a town centre, and 5 teachers serving in a province centre. There were 4 teachers teaching at 2nd Grade, 7 teachers teaching at 3rd Grade, and 6 teachers teaching at 4th Grade. All of the teachers continued teaching through distance education initiated in March, 2020.

\subsection{Data Collection}

A primary method of the data collection in phenomenological studies is the interviews. Interaction, flexibility and review questions provided by the researcher through the interviews reveal the participants' experiences with the phenomena (Creswell, 2012; Yildirim \& Simsek, 2013). The data in this study were collected via open-ended semi-structured interview questions. In this regard, one main question and probe questions in parallel with the main question were directed at the teachers. The question posed to the teachers during the interviews was "What did you need in your previous online teaching process and what do you need now?". The interviews were 
performed in an online mode due to the pandemic. The interviews were initiated via a program enabling online meetings after obtaining consents from the teachers. The duration of the interviews ranged from 34 minutes (the shortest) to 41 minutes (the longest).

\subsection{Data Analysis}

The analysis of the data obtained in phenomenology research addresses at revealing experiences and meanings (Creswell, 2012). Descriptive analysis method was used for analyzing the data. The interviews were deciphered by the researchers. A total of 44 Word pages were obtained from audio recordings of the interviews. The theoretical framework of TPACK introduced by Mishra and Koehler (2006) was used for during the conduct of the descriptive analysis. The components of TK, CK, PK, TCK, TPK, PCK constituted this theoretical framework, and themes, sub-themes and patterns were sought in the deciphered text. The answers for the same question were written one under the other in order to make it easier to reveal sub-themes and patterns. The views falling under the same theme were brought together in the coding. The obtained sub-themes and patterns were explained in relation to the experienced phenomenon. Furthermore, the themes and subthemes were also visualized.

\subsection{Trustworthiness}

Purposeful sampling, thick description, member checking, and intercoder agreement strategies were used in order to provide the trustworthiness of this study (Creswell, 2007; Creswell, 2012; Merriam, 2013). The classroom teachers who experienced the phenomenon personally constituted the participant group of this study within the scope of purposeful sampling. The study group was chosen among the classroom teachers who taught online between March, 2020 and October, 2020, as it was considered that they would better reflect lives, experiences and meanings. The purpose of including the classroom teachers who had different professional seniority into this study was to reach insights into the perspectives of the classroom teachers from various backgrounds. The points stressed by the teachers during the interviews were reflected in detailed descriptions. In this respect, the views highlighted by the teachers were given in thick descriptions under the themes. Moreover, member checking was conducted to enhance the credibility of the research (Creswell, 2007; Creswell, 2012; Merriam, 2013). Another expert coded the themes obtained by the researchers once again. Intercoder agreement between the researchers was calculated through the formula of [Agreement / (Agreement + Disagreement) x 100] proposed by Miles and Huberman (1994). The agreement ratio between the researchers was found as $90 \%$. Furthermore, the findings obtained from this study were compared to the findings available in the literature.

\section{Findings}

This part of the study revealed the classroom teachers' experiences in online education during the COVID-19 pandemic period in terms of TPACK theoretical framework. In this regard, the competencies emerging in terms of all components when the experiences of classroom teachers in online education were evaluated in relation to the TPACK are given in Figure 2. In Figure 2, each component of TPACK and what their experiences are within the scope of each component were illustrated. It comprises a detailed description of classroom teachers' experiences during the COVID-19 in terms of each component presented in Figure 2 from this part of the research findings. 


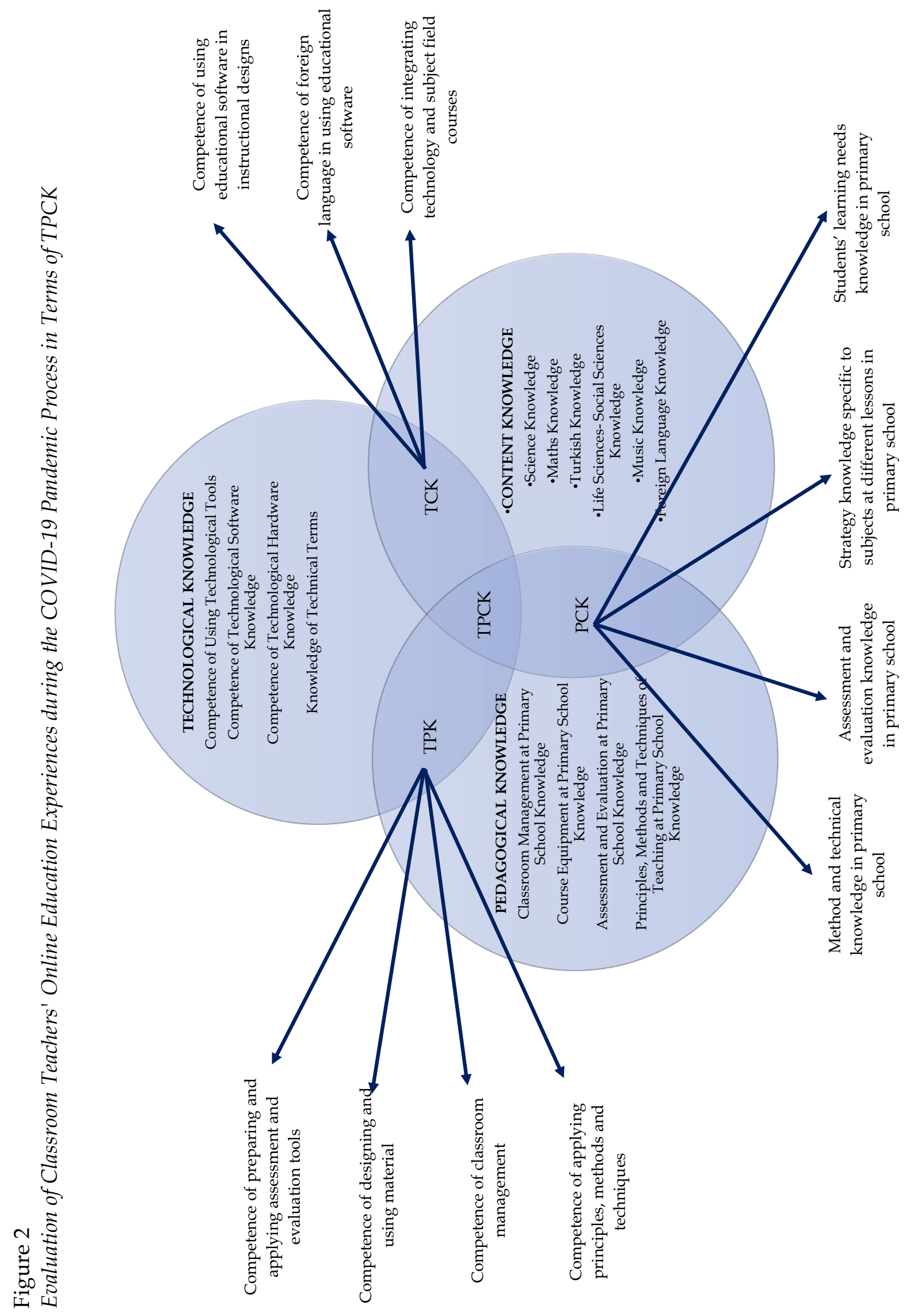




\subsection{Technological Knowledge (TK) Competence}

When the online teaching experiences of the classroom teachers during the COVID-19 period were evaluated in terms of TPACK, four sub-themes were revealed under the theme of TK competence. These were the competencies of technological tools use, software knowledge, technological hardware knowledge and technical terms knowledge (see Figure 2). All of the classroom teachers in the study group of the research stated that they did not have a problem with the use of technological tools in terms of hardware. They expressed that they had technological hardware knowledge. Moreover, the participants reported that they did not have enough knowledge in terms of software and technical terminology in the online education. However, it was seen that all of the teachers experienced problems in using Zoom program integrated with "EBA" in Turkey in terms of software knowledge and technical terms knowledge during the online education. During the interviews, the teachers stated that they could not actively use the interface (whiteboard, file upload, authorize, chat, etc.) of the Zoom program. The teachers had difficulty in coping with the process, as languages of the software were in other languages except from Turkish, some technical terms (start, end, stop share, share screen, etc.) were used in software (Zoom, Kahoot, Nearpod, etc.), and they came across some technical terms (download, upload, sign in, etc.) while searching for materials, activities, measurement tools, etc. on the Internet.

Considering the online teaching experiences of the teachers in the study group during the COVID-19 period, it can be stated that the female teachers and the teachers who had higher professional seniority had less competencies in terms of TK. Examples of the views expressed by the teachers are as follows:

FT1: I feel the deficiency of these points substantially. For example, I don't know English...I could use foreign subject area resources efficiently as they are well-prepared. I want to benefit from several videos on which students can ask and answer questions regarding science lessons. I am constantly in search of these kinds of activities. How can I do this? What kinds of applications are available? Personally, I always suffer from these issues...

FT2: ....My students have a tendency for technology use, but I am not as competent as they are. They use the technology quite well; they even describe how the things work. But we, as teachers, have a lot of deficiencies in using the technology. We cannot use these programs and tools ideally. We started even using Smartboard recently...

MT5: We experienced the first problems while opening Zoom. I had difficulty in using the interface of the Zoom as I don't know English well. I am still not proficient in using Zoom, but I can use it as much as I need. We have problems regarding the language.

\subsection{Content Knowledge (CK) Competence}

In terms of CK, it was revealed that the participants had sufficient CK in science, maths, Turkish, life studies, social studies, and music in different grades. While the novice teachers expressed that they were competent in the subject areas, as they had recently graduated from universities; the teachers with higher professional seniority expressed that they were competent in the subject areas, as they had been teaching similar topics for years. However, all of the teachers in the study group stated that they had insufficient knowledge of foreign language, which could be evaluated in CK. Especially the teachers serving in villages and in multi-grade classes stressed that they had problems in teaching English. Examples of the views expressed by the teachers on these issues are as follows:

MT5: ...I had covered main lessons such as maths, life sciences, Turkish, and science so far. I did not have any difficulties in the lessons as I used the materials which I had downloaded beforehand...

MT4: ... I think that the main lessons were not as successful as in the traditional face-to-face lessons, but we covered main lessons without any big problems in a way or another... 


\subsection{Pedagogical Knowledge (PK) Competence}

From the perspective of PK, the classroom teachers stated that they had a good command of classroom management, course tools and materials, assessment and evaluation and teaching principles, methods and technical knowledge at different grades (grades 1-4) in primary school. While the novice teachers expressed that they were pedagogically competent, as they had recently graduated from universities; the teachers with higher professional seniority expressed that they were pedagogically competent, as they had been teaching for years. Examples of the views expressed by the teachers on these issues are as follows:

FT7: ...In assessment and evaluation process, we do not have any kind of testing tool to assess the students at 2 nd grade and I can clearly see the improvement in the students who do assignments and participate in the lessons regularly when I evaluate them individually...

MT3: ...I definitely use the materials that I design myself such as a piece of writing, an impressive activity in my lessons...

MT4: ...I tried to make animation as in drama, we did in Turkish lessons, human rights lessons. That was great and we could do it in math lessons, but there were not any appropriate preparation and objectives for this...

\subsection{Pedagogical Content Knowledge (PCK) Competency}

In terms of PCK as another competence, four sub-themes emerged (Figure 3). These involved the processes of principle, method and technical knowledge, assessment and evaluation knowledge, strategy knowledge peculiar to the subjects in different courses, knowledge of the learning needs of students at primary school. All of the classroom teachers in the study group expressed that they

\section{Figure 3}

Competences of the classroom teachers regarding PCK

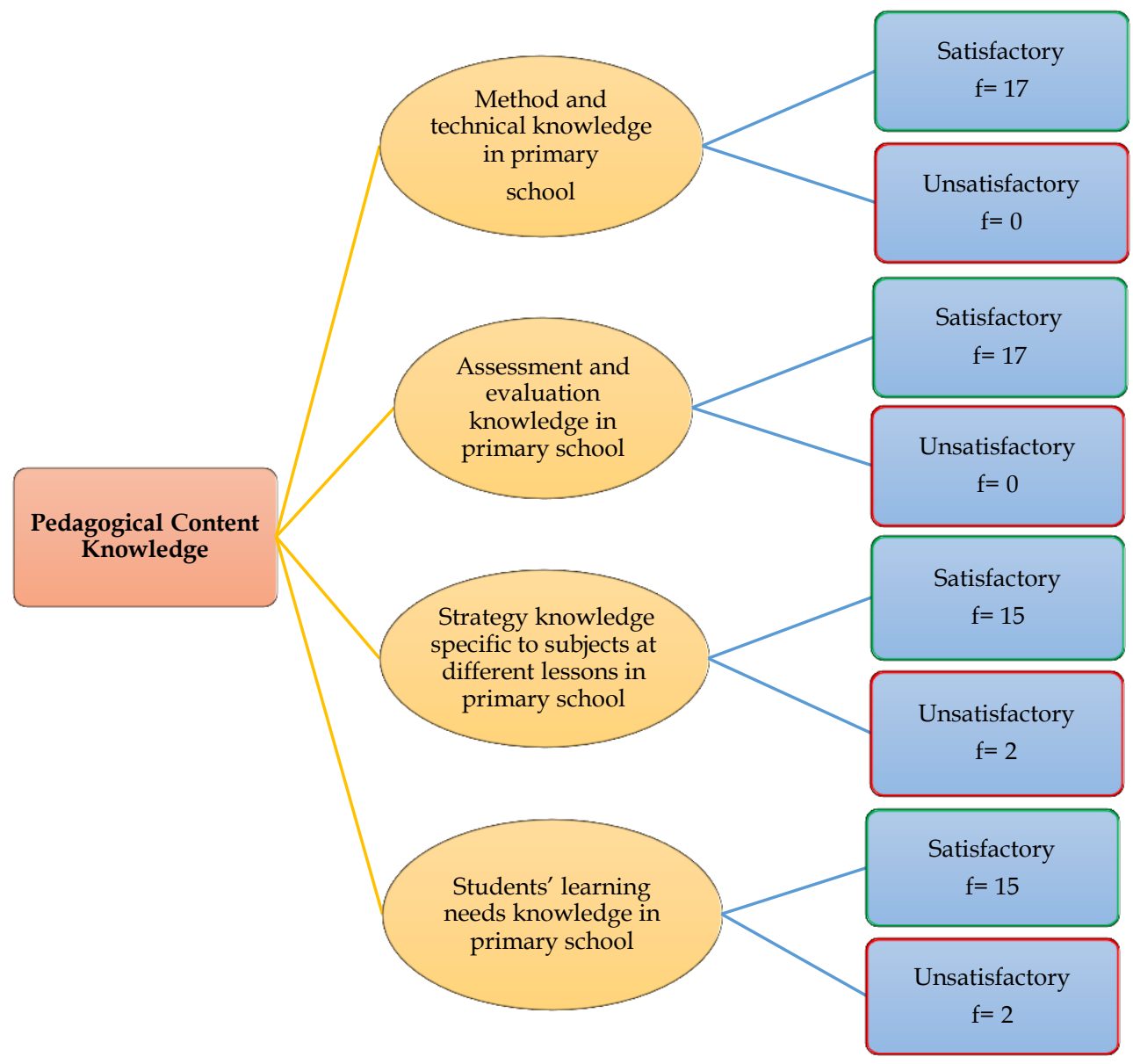


felt competent in principle, method and technique within PCK at primary school. Similarly, while all of the teachers regarded themselves competent in assessment and evaluation at primary school, 2 teachers did not consider themselves competent in strategy knowledge peculiar to the subjects in different courses and knowledge of the learning needs of students at primary school. These teachers had less professional seniority in comparison to the others, and they stressed the insufficient education that they had taken during their university education as a reason for this incompetency.

FT9: ... For example, we covered the subject of rocks in the science class. In this regard, the substance that determines structure of rocks is called mineral. The word "mineral" is itself complex for the students, and I try to solve this kind of problems via games, puzzles, etc...

FT10: ...Currently, I am good at handling this situation. At least for 2 weeks, I have been using different channels, tools, and resources. One of them is Morpa Kampüs. I became a member and started to cover the lessons based on this applicaton in an ordered way, and the students are satisfied with activities and assessment. I pause the activities during the application and explain the important points during the lessons when necessary...

MT7: ...I perform better with the help of mimics, gestures, and stories in the conventional classroom, but this does not apply in online teaching, and we need to know how to raise students' interests. This is crucial and we need to improve our teaching processes in online teaching. We are already experienced in conventional classrooms, but we still have difficulties when it comes to online teaching...

\subsection{Technological Pedagogical Knowledge (TPK) Competence}

Online teaching experiences of the teachers during the COVID-19 period with regard to the TPK competency, four categories were emerged (see Figure 4). These were the competencies of preparing and applying assessment and evaluation tools, classroom management, material development and application, and use of teaching principles, methods and techniques.

Figure 4

Competences of the classroom teachers regarding TPK

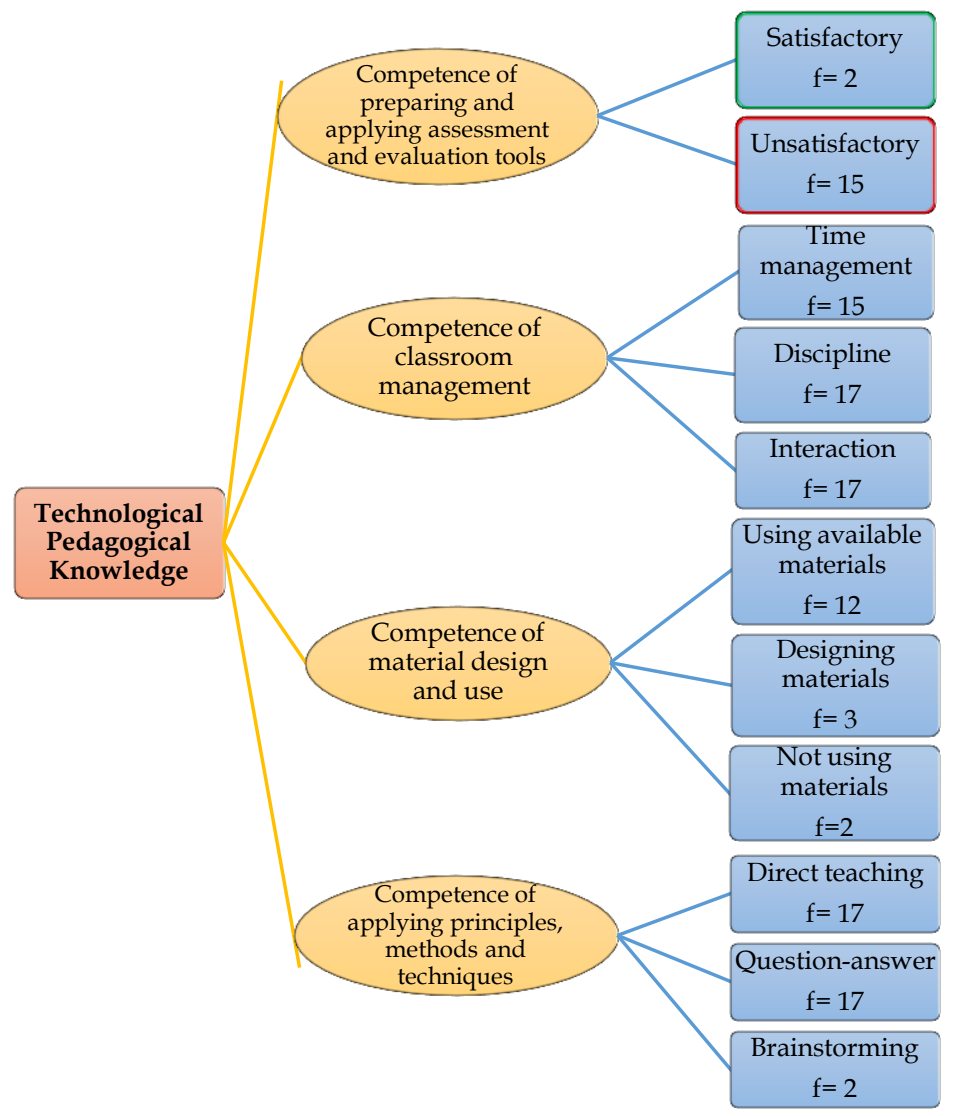


The teachers expressed that they were not competent in classroom management within the scope of TPK during the online education. They expressed that they were not competent in timemanagement, eliminating discipline problems $(\mathrm{f}=17)$, and enhancing teacher-student and studentstudent interactions during classroom management. They stated that they handled these kinds of problems during face-to-face education easily and said that online courses had peculiar features to cope with. It can be stated that they had no experiences and knowledge on how to deal with these issues during online education. Examples of the views provided by the teachers on these issues were as follows:

FT2: ... Most of the students try to learn topics in an environment where everybody talks concurrently. This takes much time as students get excited about this new learning environment...

FT3: ...For example, the students' brothers/sisters, parents, shortly everybody at home, join online lessons. You teach only students at conventional classrooms, but their family members join online courses as well. This makes things a little bit difficult for us as teachers...

ET2: ... There are many deficiencies, many disconnection problems...Students leave the PC and do not listen to lessons. We cannot make eye contact with our students, as it is called virtual environment. This is not what I previously expected from online education, I expected better performances from online education...

Considering the material development and application competency, most of the teachers used the ready materials available on the Internet. These materials are mostly videos, PowerPoint presentations, photographs related to the subjects. While 3 of the teachers stated that they were competent in preparing materials suitable for the subjects, 2 of the teachers indicated that they did not prepare and use materials during online education. Examples of the views provided by the teachers on these issues are as follows:

MT3: ...I try to do my best. I watch the available materials myself firstly and then, I have my students watch them. Designing something from the very beginning is quite hard, but it is easier to see and synthesize of things. I certainly design and integrate my own materials into the lessons, and I also prefer predesigned materials as they are less time consuming...

FT8: ...The physical facilities of our school are quite well. I find and use many things such as block cubes, cones, and three-dimensional tools, etc. whenever I need. If you ask me what I use now, I benefit from a Web site called 'Okulistik' to show abstract concepts...

When the online teaching experiences of the teachers in the study group during the COVID-19 period were evaluated in terms of teaching principles, methods and techniques competency within the scope of TPK (Figure 4), all of the teachers ( $\mathrm{f}=17$ ) preferred direct instruction and questionanswer methods during online education. Only two of the teachers mentioned to have used brainstorming method besides these methods. They stressed that they could use different educational principles, methods and techniques (drama, six thinking hats technique, role-playing, etc.) in conventional face-to-face lessons while they had difficulty in applying such kinds of educational principles, methods and techniques, as they had not had any experiences of online education process. Examples of the views provided by the teachers on these issues are as follows:

FT2: ...We apply teaching methods and techniques in our conventional face-to-face lessons. But, it is very difficult to apply the methods and techniques (brainstorming, discussion, discovery teaching strategy, etc.) in online lessons. We can only apply direct teaching and question-answer techniques...

MT3: ...I cannot use all of the methods and applications in my online lessons currently, maybe there are the ones who can. I cannot overcome all of these. I have communication problems with my students, I cannot reach them. If you ask me, I am unable to use principles, methods and techniques...

\subsection{Technological Content Knowledge (TCK) Competence}

Three sub-themes were emerged from the online teaching experiences of the teachers in terms of TCK competence. These were sequenced as using educational software in instructional designs, 
foreign language success in using educational software, and integration of technology and subject area lessons.

Figure 5

Competences of the classroom teachers regarding TCK

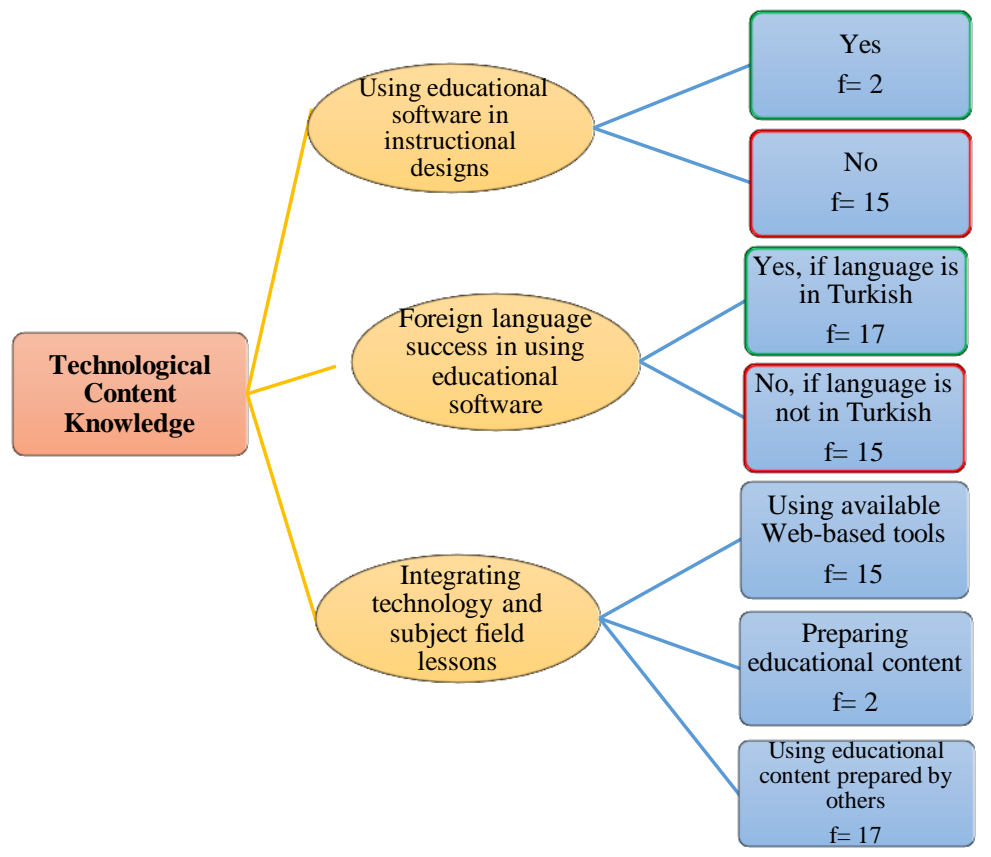

As shown in Figure 5, most of the teachers reported that they were incompetent in using educational software in instructional designs within TCK competence. Only two teachers stated that they could use educational software while designing teaching process. These teachers maintain the processes with the help of Web 2.0 tools. They stated that they shared activities by setting up Blogs and Web pages, they organized quizzes and integrated them into lessons through programs such as Kahoot. The spouses of teachers who used these tools were computer and instructional technology teachers. They expressed that they got support from their spouses for using Web 2.0 tools in online education. Examples of the views provided by the teachers on these issues were as follows:

FT9: ...As the available ones are more practical for me, I prefer them mostly. I sometimes prepare myself, if have chance. The students liked Kahoot very much. We covered a value each month in our eTwinning project. We designed a Kahoot study regarding the life of one of the famous deceased actors in Turkey...The parents most probably participated in the activity as well. I would design activities related to Kahoot...

FT1: ...I did not have any difficulty as my spouse is a computer engineer. I learn many things before everybody else. But, this situation is quite different for most of the other teachers and they have problems even in using Zoom...

In terms of their foreign language success in using educational software, all the teachers indicated that they did not feel competent on this issue. They stated that if the language of software were in Turkish, they would be partly competent while if language of software was in a language except for Turkish, they would come across problems in using software. For this reason, most of the teachers refrain from using educational software such as Kahoot, Thinglink, and Padlet.

Considering the integration of technology and subject area lessons within TCK competence, most of the teachers expressed that they used Web-based educational tools. Among these tools are videos available in environments such as Okulistik, Morpa Kampus and EBA. It was stated that the videos available on these Web-based educational environments were used through screen share and the students watched these videos in teaching subjects and concepts during the lessons. 
The number of the teachers who prepared educational content was quite low $(f=2)$. These teachers expressed that they taught topics through blocs available in PowerPoint and Web 2.0 tools. All of the teachers who used Web-based tools expressed that they benefited from the resources prepared by their colleagues during online lessons. Examples of the views provided by the teachers on these issues were as follows:

FT8: ...If you ask me how I cover my lessons, for example, I benefit from a Web page called Okulistik...

FT10: ...I think I have handled the processes quite well at least for two weeks. There are some tools that I use and one of them is Morpa Kampüs. I am a member of Morpa Kampüs, and I covered my subjects based on the activities available in Morpa Kampüs. I deliver lessons in an orderly manner through Morpa Kampüs and I highlight important points when necessary...

MT4: ...YouTube is very useful. There are many animations available in Morpa Kampus, Okulistik and EBA. We benefited from handy and available materials of these Web-based tools, pages.

\section{Discussion, Conclusion and Suggestions}

This paper investigated online teaching experiences of classroom teachers during COVID-19 period in terms of the components of TPACK. Regarding the TK, all classroom teachers indicated that they had hardware knowledge about technological equipment, and they did not have any problems in using these tools. Among the possible reasons of the obtained results can be that they are inclined to use technology and technology has taken its place in all aspects of our lives (Kuyumcu Vardar \& Acar, 2018; Sar1 \& Akbaba-Altun, 2015). However, it was observed that the software knowledge and technical term knowledge within TK of the teachers were low. The teachers had difficulties due to non-Turkish software (such as Kahoot, Nearpod, Zoom) and technical terms in foreign languages (such as share screen, upload, download) encountered during the use of technology in online education. Similar difficulties of teachers are also stated by different researchers. For instance, Wan (2020) stated that most of the teachers did not have sufficient knowledge on technological devices and they had difficulties in carrying out their lessons during COVID-19. Similarly, Demir et al. (2011) reported that teachers' competencies regarding the opportunities of the technology they used were not at a desired level. Many teachers experienced the online education after COVID-19 for the first time (Sykes, 2020), and they had been unprepared for the forthcoming processes. Most of the countries do not have educational and technological software in their own languages (Kahoot, Nearpod, Zoom, etc.), and this may have left the teachers unprepared in terms of integration of the technology into lessons in online education during the COVID-19, which is why, according to Wan (2020), technology and online education tools are complementary teaching materials that can be used in classrooms for teachers.

Another result was that the female teachers and the teachers with higher professional seniority had lower competencies in comparison to the male teachers in terms of TK. The female teachers stressed that they received help from their spouses or colleagues during the integration of technology into the education processes. The literature showed similar findings (Cleary-Tennant, 2019; Nazari et al., 2019; Roussinos \& Jimoyiannis, 2019). For example, Roussinos and Jimoyiannis (2019) stated that TK was directly related with teachers' ages, teaching experiences, and gender. The teachers with lower professional seniority were found to have higher competence levels of TK in terms of TPACK components (Browne, 2019; Nazari et al., 2019). Preservice education, experience, and understandings of the teachers with lower professional seniority affect their TK and use (Browne, 2019). Considering from this perspective, teachers sufficient knowledge and skills regarding TK can contribute to integration of the technology into learning process.

In terms of $\mathrm{CK}$, teachers with either lower or higher professional seniority were found to have sufficient knowledge on the lessons taught at primary school. However, the participants in terms of foreign language knowledge were found to be inadequate. On the other hand, teachers especially who are working in villages and teaching in multi-grade classrooms, emphasized that they had difficulties in teaching English in the online environment. These results include in some 
existing literature (e.g. Aksoy \& Bozdogan, 2019; Butler, 2004; Genc \& Kaya, 2011; Karci \& Vural, 2011; Sevik, 2009). Classroom teachers who do not know enough English and see themselves as inadequate in teaching the language they do not know because they are in a different branch, and those who did not receive support for teaching a foreign language during their pre-service education are some of the challenges they challenge (Aksoy \& Bozdogan, 2019; Genc \& Kaya, 2011; Karci \& Vural, 2011). Considering these reasons, CK related problems that classroom teachers have experienced in teaching English should not be seen as a surprise.

Similar to CK, results regarding PK showed that teachers of different professional seniority, either higher or lower, described themselves as competent in the areas such as classroom management, material development and application, preparing and applying assessment and evaluation tools, and use of teaching principles, methods and techniques. Teachers' pedagogical readiness is as important as technological preparation in the online teaching ( $\mathrm{Li}$ et al., 2019). Various studies have also underlined that teachers are more proficient in CK than in other components, and that they are aware of their pedagogical expertise (Mutanga et al., 2018; Roussinos \& Jimoyiannis, 2019). Additionally, some researchers have claimed that teachers with either lower or higher professional seniority had competency levels in terms of PK in comparison to the other components of the TPACK (Nazari et al., 2019; Riandi et al., 2018).

Results regarding the classroom teachers' PCK competence levels, four dimensions emerged: The processes of principles, methods and technical knowledge, assessment and evaluation knowledge, strategy knowledge specific to the subjects in different courses, knowing the learning needs of students in lessons at primary schools. Both teachers with higher and lower professional seniority defined themselves competent in terms of PCK. Only two of the teachers with lower professional seniority did not agree with this situation. The teachers' perceptions of their PCK competences within TPACK supported the previous results in the literature (De Freitas \& Spangenberg, 2019; Erdogan \& Mutluoglu, 2016; Karadeniz \& Vatanarttiran, 2015). However, the fact that classroom teachers with low professional seniority do not classify themselves as competent in terms of PCK may be due to the training they received in their preservice education, as stated by the interviewees. In a study conducted by Karadeniz and Vatanarttiran (2015), it was found that the teachers with professional seniority of 16 years or more found themselves more competent than the teachers with a professional seniority of 1-5 years in terms of CK and PCK.

With respect to TPK competence, teachers highlighted that they were inadequate in classroom management during online education. In more detail, teachers pointed out time management, discipline problems, and teacher-student and student-student interactions as the encountered problems. There may be many reasons behind these results. One of them may be that the target group addressed in online teaching is primary school students (6-9 ages) and there are many distractors (friends on the screens, parents and brothers/sisters at homes, etc.) in the learning environment for this group of students. Another possible reason may be that the classroom teachers started to teach in the online environment contexts in an intensive way without any prior experience, and this resulted in management problems in terms of time, discipline, and interaction. This result was also highlighted by Yüce (2019), who noted classroom management as a problematic aspect of online education by instructors.

Teachers' experiences in connection to material development and application in terms of TPK showed that most of the teachers were realized to use the materials (videos, PowerPoint presentations, photos related to subjects, etc.) available on the Internet. Furthermore, it was determined that two of the teachers did not prepare any course materials and used all of the course materials from the Internet during their online teaching. These experiences provided regarding the technology were in parallel with the studies conducted both nationally and internationally. Teacher's material preferences such as presentations, scanned materials, etc. are connected on enhancing students' critical thinking skills, and provide rich learning environments (Demir et al., 2011; Richardson, 2009; Sarı \& Akbaba-Altun, 2015). Even though most of the classroom teachers 
use the technology as a presentation tool or image reflection tool, they are unaware of the ICT that can be used in lessons (Serow \& Callingham, 2011).

In terms of teaching principles, methods and techniques, teachers stated that they mostly prefer direct teaching and question-answer methods during their online instruction. Although they could use different types of teaching principles, methods and techniques (drama, six thinking hats technique, role-playing, etc.) in the face-to-face education, they had difficulties in using such teaching principles, methods and techniques in the online teaching environment. This may be due to the fact that they had little or no experience on the online education and they had lack of knowledge and skills on how to integrate different teaching principles, methods and techniques into the online teaching. Only two teachers stated that they used brainstorming technique besides direct teaching and question-answer methods. Although teachers claimed that they had PK to use different teaching, principles, methods and techniques in their classrooms in face-to-face education, Roussinos and Jimoyiannis (2019) emphasized that teachers could not effectively incorporate their PK into the online teaching-learning process due to the gap between information and communication technology skills and knowledge of effective pedagogical approaches. Therefore, teachers need to know how to use digital technologies through authentic, inquiry and collaborative learning activities in order to create advanced learning environments that support the process of active building knowledge of students (Roussinos \& Jimoyiannis, 2019). In this context, it can be claimed that pre-service education is of great importance in ensuring the effective integration of technology and PK in future teacher (Sar1 \& Akbaba-Altun, 2015; Sarı \& Özerbaş, 2013) because of the teachers' statements regarding the insufficient training in terms of integration of these two knowledge that they had received during the undergraduate education. Similarly, it should be noted that in-service training for effective integration of technology and pedagogy knowledge would contribute to TPACK skills of the teachers.

Within the scope of TCK, it was found that teachers stated that they do not consider themselves sufficient using educational software in instructional designs. It can be said that the teachers had a lack of knowledge and experience in integrating the teaching of subjects of different courses with technological tools and equipment in online education. The teachers benefited from videos related to the courses on the educational web pages of Egitimhane, Morpa Kampus etc., presentations and materials (resource book, questions, etc.) on subjects available on the Internet since they did not know how to integrate their field knowledge with technology while teaching the subjects in their online teaching during the pandemic. However, various technological tools and materials can be integrated with online education environments that support different learning-teaching strategies and objectives. For example, tools such as virtual manipulatives for teaching in mathematics subjects, virtual museum, Google Earth for teaching in life sciences and social sciences, classroom Bundle, science kit for teaching in science lessons, and bubble draw for teaching in visual arts lessons in primary school can be adopted. Moreover, it is possible to combine the teaching of different courses with technological environments by using Web 2.0 tools (Kahoot, Nearpod, Blogs, Google Docs, etc.) in primary school.

Two of the teachers participated in the current study stated that they used some of the Web 2.0 tools. These teachers created blogs and webpages to share activities, organize quizzes there through programs such as Kahoot and integrate them with their lessons. They stated that they integrate pedagogy and CK into each other by getting support from their spouses who were teachers of information technologies. However, one of the reasons why most teachers cannot integrate technology with CK may be due to the educational software being in a foreign language. The fact that the teachers did not know any languages other than Turkish, which is their mother tongue, and that most of the Web 2.0 tools are in English, may be obstacles to effective technology and CK integration as stated in the CK component. Another reason may be the teachers' being caught unprepared to distance education with a sudden transition. It can be stated that the teachers did not have sufficient time to explore the Web 2.0 tools such as Kahoot, Nearpod, Blogs, Google docs etc. in order to use them in teaching the subjects during online education. 
Considering that the use of technology intensively in the teaching-learning process in Turkey has been for 10 years, the fact that the classroom teachers, especially those with low professional seniority, have difficulty or are not competent in the integration of technology and CK as much as the teachers with high professional seniority brings to mind the inadequacy of undergraduate education in these subjects. As stated by the teachers during the interviews, taking only Information and Communication Technologies course during their undergraduate education, knowing only technological tools in hardware within the scope of this course and covering only the use of Microsoft Office as a software program may leave teachers insufficient to integrate technology and CK effectively. It is thought that the reduction of Information and Communication Technology courses to one semester, especially after the update of curriculum at education faculties, would bring along problems in terms of the technological competence of teachers in the future. For this reason, only introducing technologies to teachers in both pre-service and in-service trainings and teaching them how to use these technologies would lead to the development of an education system at the level of knowledge. Teaching teachers how to use technology to its full capacity will inspire them to engage in higher-order thinking, autonomous learning, and lifelong learning (Kurt, 2015). Teaching technological tools and materials such as Web 2.0 tools, Web 3.0 technologies, virtual software, etc. to teachers and providing them with experiences of combining them with content and PK would enable teachers to discover the true potential of technology. This way, it can be ensured that teachers can prepare educational contents by taking into account the features of subjects, individual differences and grades by themselves instead of using the content prepared by their colleagues in online education.

In conclusion, when the online teaching experiences, technology uses, competencies and professional training needs of the classroom teachers in the study during the COVID-19 period were considered as a whole; it was revealed that the teachers did not use digital tools primarily for pedagogical purposes. Therefore, the teachers need extensive pedagogical support when designing digital teaching (Amhag et al., 2019). Although the teachers considered themselves competent in TK, CK, PK and PCK components of TPACK, it can be said that they were not successful after considering the experiences arising from the integration of each of these components with technology. The fact that most of the classroom teachers perform their online education by benefiting from the Web pages of interactive educational environments (Egitimhane, Morpa Kampus, etc.) and the presentations and materials available on the Internet (resource books, questions, etc.) may not mean that an effective and rich learning-teaching process is ensured. According to Wang and Woo (2007), teachers' reflecting resource books via projections, ensuring the control of assignments, changing learning environments by sharing visuals and videos on the Internet in order to help student understand some concepts show that they use the technology at a micro level (on a course basis), in other words, they use it only to change the environment (Hughes, 2005). These results suggest that 21st century teachers need to develop their knowledge and skills in terms of CK, PK, TCK, and TPK that emerge with the transfer of these knowledge to technological processes and TPACK that forms the intersection of all information. For this reason, the education institutions that train primarily pre-service teachers need to provide the effective integration of technology into lessons in order to create significant awareness in terms of training prospective teachers in a well-equipped way. Afterwards, the regular trainings to be provided to teachers regarding development and change in technology, the use of technological tools and materials during in-service training processes instead of focusing solely on the use of technology in extraordinary times such as the COVID-19 outbreak will undoubtedly play major roles in the development of TPACK competence, which means effective technology integration.

This research also contains some limitations. The researchers could not conduct observations to enhance the credibility of the research. In this respect, observations for different lessons can be carried out and their findings can be compared with the findings obtained from this research in order to reveal the online teaching experiences of the classroom teachers. As a result, it can be determined which component(s) of TPACK classroom teachers are more skilled. 


\section{References}

Acar, F. (2021). Uzaktan eğitimde uygulamalı eğitimin ilkeleri ve etkiliğini arttırmaya yönelik öneriler [Principles of applied education in distance education and suggestions to increase its effectiveness]. In İ. Genç, M. Koç, H. Keskin, A. Adıgüzel (Eds.), Pedagojik anlayışın uzaktan eğitime uyarlanması [Adapting the pedagogical approach to distance education] (pp.83-92). Pegem.

Aksoy, E. \& Bozdogan, D. (2019). Determining the English proficiency levels and needs of primary school teachers concerning their English language teaching experiences. Elementary Education Online, 18(3), 959976. https://doi.org/10.17051/ilkonline.2019.609207

Amhag, L., Hellström, L., \& Stigmar, M. (2019). Teacher educators' use of digital tools and needs for digital competence in higher education. Journal of Digital Learning in Teacher Education, 35(4), 203-220. https:// doi.org/10.1080/21532974.2019.1646169

Atakan, I. (2019). Pre-service science teachers' TPACK efficacy levels and technology integration quality: Application of TPACK-IDDIRR model [Unpublished Doctoral dissertation). Middle East Technical University, Ankara.

Bayrakdar, S. \& Guveli, A. (2020). Inequalities in home learning and schools' provision of distance teaching during school closure of COVID-19 lockdown in the UK. Economic and Social Research Council.

Brower, M. \& Vlachopoulos, P. (2018). A critical analysis of technology-enhanced learning design frameworks. British Journal of Educational Technology, 49(6) 981-997. https://doi.org/10.1111/bjet.12668

Browne, C. C. (2019). A qualitative multiple case study investigating novice elementary teachers' use of information communication technologies in 1:1 classrooms (Publication No. 27540412) [Doctoral dissertation, Northcentral University]. ProQuest Dissertations and Theses Global.

Burgess, S. \& Sievertsen, H. H. (2020). Schools, skills, and learning: The impact of COVID-19 on education. VoxEu. Retrieved from https://voxeu.org/article/impact-covid-19-education

Butler, Y. G. (2004). What level of English proficiency do elementary school teacher need to attain to teach EFL? Case studies from Korea, Taiwan, and Japan. TESOL Quarterly, 38(2), 245-278.

Chai, C. S., Koh, J. H. L. \& Tsai, C. C. (2013). A review of technological pedagogical content knowledge. Educational Technology and Society, 16(2), 31-51.

Cleary Tennant, A. E. (2019). Using teachers' experience with technology to understand their learning and teaching styles (Doctoral dissertation). Available from ProQuest Dissertations and Theses Global database. (UMI No. 13897669).

Cox, S. \& Graham, C. R. (2009). Diagramming TPACK in practice: Using an elaborated model of the TPACK framework to analyze and depict teacher knowledge. Tech Trends, 53(5), 60-69. https:// doi.org/10.1007/s11528-009-0327-1

Creswell, J W. (2007). Qualitative inquiry and research design: Choosing among five approaches. Sage.

Creswell, J. W. (2012). Educational research: Planning, conducting, and evaluating quantitative and qualitative research. Pearson.

De Freitas, G. \& Spangenberg, E. D. (2019). Mathematics teachers' levels of technological pedagogical content knowledge and information and communication technology integration barriers. Pythagoras, 40(1), 1-13. https:// doi.org/10.4102/ pythagoras.v40i1.431

Demir, S., Ozmantar, M. F., Bingolbali, E. \& Bozkurt, A. (2011). An investigation of elementary teachers' use of technology [Paper presentation]. 5th International Computer \& Instructional Technologies Symposium, Elâzı ̆̆, Turkey.

Ely, D. P. (1992). Trends in educational technology. Clearing house on Information Resources.

Erdogan, A. \& Mutluoglu, A. (2016). Examining primary mathematics teachers' technological pedagogical content knowledge (tpack) level according to their preferred teaching styles. OPUS International Journal of Society Researches, 6(10), 102-126.

Fathi, J., \& Yousefifard, S. (2019). Assessing language teachers' technological pedagogical content knowledge (TPACK): EFL students' perspectives. Research in English Language Pedagogy, 7(2), 255-282. https://doi.org/10.30486/relp.2019.665888

Genç, G. \& Kaya, A. (2011). The relationship between foreign language achievement and attitudes towards English courses of prospective primary school teachers. Balkesir University Journal of Institute of Social Sciences, 14(26), 19-31.

Goradia, T. (2018). Role of educational technologies utilizing the TPACK framework and 21st century pedagogies: Academics' perspectives. The International Academic Forum (IAFOR) Journal of Education, 6(3), 43-61. https://doi.org/10.22492/ije.6.3.03 
Heitink, M., Voogt, J., Fisser, P., Verplanken, L., \& Van Braak, J. (2017). Eliciting teachers' technological pedagogical knowledge. Australasian Journal of Educational Technology, 33(3), 96-109. https://doi.org/10.14742/ajet.3505

Hughes, J. (2005). The role of teacher knowledge and learning experiences in forming technology-integrated pedagogy. Journal of Technology and Teacher Education, 13(2), 277-302.

Karadeniz, S. \& Vatanartiran, S. (2015). Primary school teachers' technological pedagogical content knowledge. Elementary Education Online, 14(3), 1017-1028. http://doi.org/10.17051/io.2015.12578

Karci, C. \& Akar Vural, R. (2011). Teachers' views with regard to teaching English in multigraded classrooms. Elementary Education Online, 10(2), 593-607.

Koehler, M., Shin, T. S. \& Mishra, P. (2012). How do we measure TPACK? Let me count the ways. In R. N. Ronau, C. R. Rakes \& M. L. Niess (Eds.), Educational technology, teacher knowledge, and classroom impact (pp. 16-31). Information Science Reference.

Kurt, S. (2015). Educational technology: An overview. Retrieved from https://educationaltechnology.net/educational-technology-an-overview/

Kuyumcu Vardar, A. \& Acar, F. (2018). Quick assessment techniques used in learning teaching process. Turkish Studies, 13(11), 879-898.

Li, Y., Garza, V., Keicher, A., \& Popov, V. (2019). Predicting high school teacher use of technology: Pedagogical beliefs, technological beliefs and attitudes, and teacher training. Technology, Knowledge and Learning, 24, 501-518. https://doi.org/10.1007/s10758-018-9355-2

Merriam, S. B. (2013). Qualitative research: A guide to design and implementation. John Wiley \& Sons.

Ministry of National Education [MoNe]. (2020a). "Uzaktan eğitim" bakan Selçuk'un verdiği dersle başladı ["Distance education" started with the lecture given by Selçuk the minister]. http://www.meb.gov.tr/uzaktan-egitim-bakan-selcukun-verdigi-dersle-basladi/haber/20578/tr

Ministry of National Education [MoNe]. (2020b). Uzaktan eğitim 30 Nisan'a kadar devam edecek [Distance education will continue until April 30]. http://www.meb.gov.tr/uzaktan-egitim-30-nisana-kadardevam-edecek/haber/20585/tr

Ministry of National Education [MoNe]. (2020c). Uzaktan eğitim 31 Mayıs'a kadar devam edecek [Distance education will continue until May 31]. Retrieved October, 02, 2020, http://www.meb.gov.tr/uzaktanegitim-31-mayisa-kadar-devam-edecek/haber/20803/tr

Ministry of National Education [MoNe]. (2020d). 18 Eylül'e kadar sürecek uzaktan eğitim-döneminin yol haritası [The roadmap of the distance education-term that will last until September 18]. Retrieved October, 02, 2020, http://www.meb.gov.tr/18-eylule-kadar-surecek-uzaktan-egitim-doneminin-yol haritasi/haber/21499/tr

Miles, M. B. \& Huberman, A. M. (1994). Qualitative data analysis: An expanded sourcebook. (2nd ed). Sage.

Mishra, P. \& Koehler, M. J. (2006). Technological pedagogical content knowledge: A framework for teacher knowledge. Teachers College Record, 8(6), 1017-1054.

Mishra, P. (2019). Considering contextual knowledge: The TPACK diagram gets an upgrade. Journal of Digital Learning in Teacher Education, 35(2), 76-78. https://doi.org/10.1080/21532974.2019.1588611

Mutanga, P., Nezandonyi, J. \& Bhukuvhani, C. (2018). Enhancing engineering education through technological pedagogical and content knowledge (TPACK): A case study. International Journal of Education \& Development Using Information \& Communication Technology (IJEDICT), 14(3), 38-49.

Nazari, N., Nafissi, Z., Estaji, M., \& Marandi, S. S. (2019). Evaluating novice and experienced EFL teachers' perceived TPACK for their professional development. Cogent Education, 6(1), 1-26. https:/ / doi.org/10.1080/2331186x.2019.1632010

Polly, D. \& Orrill, C. H. (2016). Designing professional development to support teachers' TPACK in elementary school mathematics. In M. C., Herring, M. J., Koehler, \& P. Mishra, (Eds.). (2016). Handbook of technological pedagogical content knowledge (TPACK) for educators (pp. 259-269). Routledge.

Riandi, R., Apriliana, V. \& Purwianingsih, W. (2018). The analysis of 21st century teachers' ability in technological pedagogical content knowledge. Advances in Social Science, Education and Humanities Research, 212, 275-278. https://doi.org/10.2991/icei-18.2018.60

Richardson, S. (2009). Mathematics teachers' development, exploration, and advancement of technological pedagogical content knowledge in the teaching and learning of algebra. Contemporary Issues in Technology and Teacher Education, 9(2), 117-130.

Roblyer, M. D. (2006). Integrating educational technology into teaching. Merrill Prentice Hall. 
Roussinos, D. \& Jimoyiannis, A. (2019). Examining primary education teachers' perceptions of TPACK and the related educational context factors. Journal of Research on Technology in Education, 51(4), 377-397. https:/ / doi.org/10.1080/15391523.2019.1666323

Saban, A. (2007). Okul teknolojisi planlamasi ve koordinasyonu [School technology planning and coordination]. Pegem.

Sarı, M.H. \& Akbaba Altun, S. (2015). A qualitative research on classroom teachers' technology use in mathematics teaching. International Journal of Eurasia Social Sciences, 6(19), 24-49.

Sarı, M. H., \& Ozerbas, M. A. (2013). Determining classroom teachers' perceptions of technology use in primary school mathematics teaching [Paper presentation]. 12th Symposium of Classroom Teaching, Aydın, Turkey.

Serow, P. \& Callingham, R. (2011). Levels of use of interactive whiteboard technology in the primary mathematics classroom. Technology, Pedagogy and Education, 20(2), 161-173. https:/ / doi.org/10.1080/1475939X.2011.588418

Sevik, M. (2009). The teaching of modern foreign languages in primary schools and generalist class teachers. Ankara University Journal of Faculty of Educational Sciences, 42(1), 377-401.

Shulman, L. S. (1987). Knowledge and teaching foundations of the new reform. Harvard Educational Review, $57,1-22$.

Spiteri, M. \& Chang Rundgren, S. N. (2020). Literature review on the factors affecting primary teachers' use of digital technology. Technology, Knowledge and Learning, 25, 115-128. https://doi.org/10.1007/s10758018-9376-x

Sykes, D. (2020). Online education during a pandemic: Teaching and learning in home spaces. Literacies $\mathcal{E}$ language education: research $\mathcal{E}$ practice: Teaching during a pandemic, 1(1), 86-88.

Tezci, E., \& Perkmen, S. (2013). Integration of technology into the learning-teaching process from a constructivist perspective. Çă̆ıltay, K., Göktaş, Y. (Eds). Öğretim teknolojilerinin temelleri: Teoriler, araştırmalar, eğilimler [Instructional technology foundations: Theories, research, trends] (pp. 185-211). Pegem.

United Nations Educational, Scientific and Cultural Organization [UNESCO]. (2020). Global monitoring of school closures caused by COVID-19. https://en.unesco.org/covid19/educationresponse/

Voogt, J. Fisser, P. Roblin, N. P. Tondeur, J. \& Van Braak, J. (2012). Technological pedagogical content knowledge- a review of literature. Journal of Computer Assisted Learning, 29, $109-121$. https://doi.org/10.1111/j.1365-2729.2012.00487.x

Wan, Y. S. (2020). Education during Covid-19. Ideas Institute for Democracy and Economic, 19, 1-10.

Wang, Q. \& Woo, H. L. (2007). Systematic planning for ICT integration in topic learning. Educational Technology and Society, 10(1), 148-156

World Health Organization [WHO] (2020a). Naming the coronavirus disease (COVID-19) and the virus that causes it. https://www.who.int/emergencies/diseases/novel-coronavirus-2019/technicalguidance/naming-the-coronavirus-disease-(covid-2019)-and-the-virus-that-causes-it

World Health Organization [WHO] (2020b). Coronavirus disease (COVID-19) pandemic. https://www.who.int/emergencies/diseases/novel- coronavirus-2019

Yildirim, A. \& Simsek, H. (2013). Sosyal bilimlerde nitel araştırma yöntemleri [Qualitative research methods in the social sciences. Seckin.

Yüce, E. (2019). Possible problems in online foreign language teaching at a university context. International Journal of Curriculum and Instruction, 11(2), 75-86. 